\title{
DINAMIKA POLA PEMASARAN KOPI PADA WILAYAH SENTRA PRODUKSI UTAMA DI INDONESIA
}

\author{
Nia Rosiana \\ Departemen Agribisnis, Fakultas Ekonomi dan Manajemen, Institut Pertanian Bogor, \\ Jl. Kamper Wing 4 Level 5, Dramaga, Bogor. Indonesia 16680 \\ *E-mail: niarosiana@gmail.com
}

Diterima: 21/01/2020

Direvisi: $13 / 02 / 2020$

Disetujui: 08/04/2020

\begin{abstract}
ABSTRAK
Adanya market power dalam saluran pemasaran kopi diduga berpengaruh terhadap pola pemasaran kopi disetiap wilayah sentra produksi kopi utama. Adapun tujuan penelitian ini yaitu 1) menganalisis dinamika pola pemasaran kopi di lima sentra produksi kopi Indonesia dan 2) implikasi kebijakan yang dapat dilakukan dalam pengembangan pasar kopi guna meningkatkan ekonomi petani. Metode analisis yang digunakan yaitu deskriptif kualitatif yang didasarkan pada hasil survey lapang dan desk study di lima sentra produksi utama kopi Indonesia (Prov. Sumatera Selatan, Prov. Lampung, Prov. Sumatera Utara, Prov. Aceh, dan Prov. Jawa Timur). Hasil menunjukkan bahwa petani kopi di lima sentra produksi utama Indonesia menjual kopi dalam bentuk kopi asalan yang secara umum menjual ke pedagang pengumpul. Adanya kemudahan cash economy dan tidak ada perlakuan khusus untuk kopi yang dijual menjadi alasan utama petani menjual ke lembaga pemasaran tersebut. Perlunya penguatan kelembagaan (kemitraan) pada sistem pemasaran dalam upaya mengatasi keterbatasan informasi dan penentuan harga jual. Selain itu, perlunya pendampingan petani yang diarahkan pada proses sertifikasi yang berkelanjutan baik dari sisi produksi maupun ekonomi diantaranya peningkatan mutu greenbean dan kopi bubuk.
\end{abstract}

Kata kunci: Lembaga pemasaran, market power, pemasaran

\begin{abstract}
Market power influenced the coffee marketing channel in several major coffee production centers. The objectives of this study are 1) analyzing coffee marketing patterns in five Indonesian coffee production centers and 2) policy implications that can be carried out in developing the coffee market to improve the farmers' economy. The results showed that coffee farmers in Indonesia's main production centers sell coffee in the form of raw coffee that is sold to collectors/traders. The existence of a cash economic solution and no special treatment to the coffee sold is the main reason farmers sell to these marketing institutions. The institutional strengthening treatment (partnership) in the marketing system in an effort to overcome the limitations of information and the strengthening of selling prices. In addition, the need for farmer's assistance directed at the certification process that is supported both in terms of production and economy through improving the quality of greenbeans and ground coffee.
\end{abstract}

Keywords : Marketing, marketing agency, market power 


\section{PENDAHULUAN}

Kopi merupakan komoditas ekspor yang memerlukan sistem pemasaran bertahap hingga mencapai perdagangan internasional (Novita et al 2012). Di pasar internasional, kualitas serta kontinuitas produksi dapat meningkatkan daya saing suatu negara (Rosiana et al 2018). Selain itu, persaingan produksi dan kualitas merupakan upaya untuk memenuhi permintaan konsumen baik domestik maupun luar negeri (Rosiana et al 2017b). Tahun 2018, produksi kopi Indonesia mencapai 713921 ton (BPS 2019). Produksi tersebut tersebar diseluruh wilayah Indonesia dengan ketinggian minimum $300 \mathrm{~m}$ dibawah permukaan laut (BPPT Kementan 2008). Lima sentra produksi utama kopi Indonesia diantaranya berada di Provinsi Sumatera Selatan, Provinsi Lampung, Provinsi Sumatera Utara, Provinsi Aceh, dan Provinsi Jawa Timur (Tabel 1). Sentra produksi terbesar berada Provinsi di Sumatera Selatan dengan tingkat produksi mencapai 184168 ton atau 25.80 persen dari total produksi Indonesia.

Tabel 1. Produksi kopi di lima sentra produksi utama di Indonesia tahun 2018 (Ton)

\begin{tabular}{clrr}
\hline No & Provinsi & $\begin{array}{c}\text { Produksi } \\
\text { (Ton) }\end{array}$ & $\begin{array}{c}\text { Pangsa } \\
\text { Produksi } \\
(\%)\end{array}$ \\
\hline 1 & $\begin{array}{l}\text { Sumatera } \\
\text { Selatan }\end{array}$ & 184168 & 25.80 \\
\hline 2 & Lampung & 106746 & 14.95 \\
\hline 3 & $\begin{array}{l}\text { Sumatera } \\
\text { Utara }\end{array}$ & 67179 & 9.41 \\
\hline 4 & Aceh & 64812 & 9.08 \\
\hline 5 & $\begin{array}{l}\text { Jawa } \\
\text { Timur }\end{array}$ & 63760 & 8.93 \\
\hline
\end{tabular}

Sumber : BPS (2019)

Karakteristik kopi Indonesia yang ditanam di berbagai wilayah Indonesia memiliki aroma dan cita rasa yang khas. Hal ini yang menjadi keunggulan dari setiap wilayah. Secara umum, kopi dengan jenis robusta dan arabika dapat ditanam di hampir seluruh wilayah di Indonesia. Berdasarkan data Dirjenbun (2017) hanya Provinsi Sumatera Selatan yang memproduksi satu jenis kopi yaitu kopi robusta. Wilayah lainnya seperti Provinsi Lampung, Provinsi Sumatera Utara, Provinsi Aceh, dan Provinsi Jawa Timur dapat ditanam dengan dua jenis kopi tersebut. Provinsi Lampung merupakan sentra kopi robusta terbesar di Indonesia sedangkan Provinsi Aceh merupakan sentra kopi arabika terbesar di Indonesia. Persentase produksi kopi berdasarkan jenis kopi di lima sentra produksi utama Indonesia dapat dilihat pada Tabel 2.

Tabel 2. Persentase produksi kopi berdasarkan jenis kopi di lima sentra produksi utama Indonesia

\begin{tabular}{llrr}
\hline \multirow{2}{*}{ No } & \multirow{2}{*}{ Provinsi } & \multicolumn{2}{c}{$\begin{array}{c}\text { Persentase Produksi } \\
\text { (\%) }\end{array}$} \\
\cline { 3 - 4 } & & Robusta & Arabika \\
\hline 1 & $\begin{array}{l}\text { Sumatera } \\
\text { Selatan }\end{array}$ & 100.00 & 0.00 \\
\hline 2 & Lampung & 99.90 & 1.00 \\
\hline 3 & $\begin{array}{l}\text { Sumatera } \\
\text { Utara }\end{array}$ & 18.72 & 81.28 \\
\hline 4 & Aceh & 8.35 & 91.65 \\
\hline 5 & Jawa & 83.36 & 16.64 \\
& Timur & & \\
\hline
\end{tabular}

Sumber : Dirjenbun (2017)

Kopi yang diproduksi dari berbagai wilayah di Indonesia merupakan upaya dalam memenuhi kebutuhan pasar dalam negeri dan internasional. Pemenuhan pasokan atau produksi kopi dalam negeri dapat dilakukan melalui analisis pada setiap anggota rantai pasok yang membentuk jaringan rantai pasok (Rosiana et al 2017a). Dalam hal ini keterlibatan dan peran para pelaku pemasaran sangat penting mulai dari produsen, perantara, pengolah, hingga eksportir. Dalam saluran pemasaran, terdapat perbedaan marjin dalam setiap lembaga pemasaran. Hal ini ditunjukkan oleh adanya disparitas harga dalam rantai pemasaran. Rantai pemasaran 
yang panjang serta adanya market power yang dimiliki oleh pedagang perantara menjadi penyebab besarnya disparitas harga dalam rantai pemasaran (Juliaviani et al 2017). Pemasaran yang efisien terjadi saat tidak melibatkan banyak pihak meskipun total marjin pemasaran yang diterima lebih rendah dari saluran pemasaran lainnya namun keuntungan petani lebih besar dari saluran lainnya (Ridhawardani et al 2017). Menurut Cristovao (2015) bahwa pedagang besar sangat dominan dan mempengaruhi penentuan harga kopi karena jaringan kerjasama antar lembaga pemasaran yang belum berjalan dengan baik dan kelompok tani yang belum berfungsi dengan baik. Pada kondisi tersebut, petani cenderung sebagai price taker sehingga bargaining position petani lemah dalam penentuan harga.

Perbedaan market power akibat dari struktur pasar yang terbentuk di setiap sentra produksi utama memungkinkan adanya perbedaan pola pemasaran kopi. Sebagai contoh, struktur pasar kopi di Provinsi Aceh khususnya di Kab. Aceh Tengah dan Kab. Bener Merah menghadapi struktur pasar oligopsoni sehingga memungkinkan eksportir sebagai pembeli melakukan kolusi dalam mengendalikan harga pasar (Putri et al 2013). Berbeda halnya di Provinsi Lampung terdapat kekuatan monopsoni atau oligopsoni dalam aktivitas pemasaran kopi (Noer et al 2012). Hal ini ditunjukkan oleh laju perubahan harga kopi di tingkat petani lebih kecil dari laju perubahan harga di tingkat eksportir. Struktur pasar di Provinsi Jawa Timur khususnya di Kec.Sumber Wringin Kab.Bondowoso sama dengan di Provinsi Lampung yang berdampak pada rendahnya harga yang diterima petani (Purwatiningsih dan Ismanto 2018). Berdasarkan penjelasan tersebut, maka adanya market power dalam saluran pemasaran kopi diduga berpengaruh terhadap pola pemasaran kopi disetiap wilayah sentra produksi kopi utama. Maka, tujuan penelitian ini yaitu 1) menganalisis dinamika pola pemasaran kopi di lima sentra produksi kopi Indonesia dan 2) implikasi kebijakan yang dapat dilakukan dalam pengembangan pasar kopi guna meningkatkan ekonomi petani.

\section{METODE}

Metode analisis yang digunakan dalam tulisan ini yaitu deskriptif kualitatif yang didasarkan pada hasil survey lapang dan desk study di lima sentra produksi utama kopi (Prov. Sumatera Selatan, Prov. Lampung, Prov. Sumatera Utara, Prov. Aceh, dan Prov. Jawa Timur). Peneliti menggunakan data yang diperoleh dari berbagai sumber diantaranya Badan Pusat Statistik, Direktorat Jenderal Perkebunan Kementerian Pertanian, jurnal-jurnal, serta berbagai hasil penelitian yang relevan dalam menganalisis dinamika pola pemasaran kopi di lima sentra produksi kopi. Peneliti pula melakukan wawancara langsung dengan para pelaku utama seperti petani, pedagang, dan pengolah kopi di salah satu sentra produksi kopi robusta di Indonesia yaitu di Kab.Lampung Barat Prov. Lampung. Selain itu, peneliti melakukan wawancara dengan para ahli perkopian di Prov. Lampung dan Prov. Jawa Timur dalam upaya merumuskan kebijakan pemasaran kopi.

\section{HASIL DAN PEMBAHASAN}

\section{Pemasaran Kopi di Provinsi Sumatera Selatan}

Pangsa produksi kopi terbesar di Indonesia berada di Provinsi Sumatera Selatan dengan produksi mencapai 184168 ton pada tahun 2018 (BPS 2019). Produksi tersebut tersebardi beberapa sentra produksi diantaranya di Kab. OKU Selatan, Kab. Muara Enim, Kab. Lahat, dan kabupatan lainnya. Tingkat produksi di tiga kabupaten tersebut secara berurutan yaitu 33.15 persen, 20.87 persen, dan 16.99 persen dari total produksi di Provinsi Sumatera Selatan. Secara umum, kopi yang 
diusahakan di Provinsi Sumatera Selatan didominasi oleh kopi berjenis kopi robusta. Namun, terdapat pula kopi berjenis Liberika yang memiliki potensi untuk dikembangkan. Hal ini dikarenakan di Provinsi Sumatera Selatan terdapat lahan gambut sehingga dalam pemanfaatannya dapat ditanami kopi dalam rangka mendukung program restorasi lahan gambut. Pasar kopi liberika dijual ke pasar lokal dan negara tujuan ekspor utama yaitu Malaysia dan Singapura (Waluyo dan Nurlia 2017). Sistem pemasarannya masih dilakukan secara konvensional dimana petani menjual kopi tersebut ke pedagang pengumpul untuk dipasarkan lagi.

Pemasaran kopi di Provinsi Sumatera Selatan dilakukan dari produsen (petani), pedagang pengumpul, pengolah, hingga ke eksportir. Umumnya kopi robusta yang berasal dari Sumatera Selatan di ekspor ke Eropa dan Amerika Serikat. Namun, dalam proses pemasaran kopi ke negaranegara tersebut bahwa eksportir kopi di Sumatera Selatan mengalami hambatan (Markoni 2012). Hambatan-hambatan tersebut diantaranya tarif, non tarif, standar kualitas, syarat-syarat administrasi dan kesulitan mendapatkan pembeli bagi eksportir baru. Sedangkan hambatan lain yang dihadapi eksportir ketika memasarkan kopi ke Amerika Serikat diantaranya hambatan kebijakan pemerintah, tarif yang tinggi dan pemasaran. Oleh karena itu, upaya yang dilakukan oleh eksportir Indonesia dalam memasarkan kopi ke pasar internasional dapat melalui perwakilan importir yang ada di indonesia atau melalui perwakilan dagang asing yang terdapat di negara tujuan.

\section{Pemasaran Kopi di Provinsi Lampung}

Kopi yang dihasilkan di Provinsi Lampung didominasi oleh kopi berjenis kopi robusta. Wilayah sentra produksi utama di Provinsi Lampung diantaranya Kab. Lampung Barat dan Kab.
Tanggamus. Tingkat persentase produksi di Kab.Lampung Barat mencapai 49.93 persen dari total produksi di provinsi tersebut. Selanjutnya diikuti oleh Kab.Tanggamus dengan tingkat produsen terbesar kedua yang mencapai 27.37 persen dari total produksi Provinsi Lampung. Keduanya merupakan sentra produksi terbesar meskipun terdapat wilayah lainnya seperti Kab.Way Kanan yang berkontribusi menambah produksi kopi hanya sebesar 8.06 persen di provinsi tersebut. Sedangkan sisanya diproduksi oleh wilayah lainnya dengan persentase masing-masing kurang dari 10 persen.

Aktivitas pemasaran kopi di Provinsi Lampung terbagi menjadi dua yaitu aktivitas pemasaran yang dilakukan oleh petani sertifikasi dan petani nonsertifikasi. Standar sertifikasi mengacu pada SNI 6729:2013 mengenai sistem pertanian organik. Umumnya petani sertifikasi dapat bekerjasama dengan Gabungan Kelompok Tani (Gapoktan) atau dengan buyer centre perusahaan seperti PT.Nestle. Selain itu, petani sertifikasi memiliki jaminan untuk mempertahankan pasar. Contohnya petani di Kec.Air Hitam Kab. Lampung Barat yang telah memiliki sertifikasi organik dari Indonesian Organic farm Certification (INOFICE) akan memperoleh harga premium (premium price) yaitu harga yang lebih tinggi dari harga di pasar. Hal ini dikarenakan adanya perbedaan kualitas dari petani yang nonsertifikasi. Perbedaan harga tersebut ditentukan berdasarkan pada mutu atau grade sepeti persentase kadar air dan persentase kotoran (abu, kulit tanduk, dan gelondongan. Berbeda halnya dengan petani nonsertifikasi yang menjual kopi ke tengkulak (pedagang pengumpul). Penelitian Pratiwi et al (2019) menunjukkan bahwa petani kopi di Kab. Tanggamus memilih saluran pemasaran ke tengkulak (pedagang pengumpul) lalu ke pedagang besar dan pengecer dikarenakan tiga faktor utama. Faktor tersebut diantaranya jarak, kemudahan 
pinjaman uang, dan tidak ada perlakuan khusus kopi yang dijual. Oleh karena itu, perlunya pendampingan pada petani khususnya proses sertifikasi sehingga keberlanjutan produksi dan manfaat ekonomi dapat dirasakan oleh petani. Hal ini sejalan dengan penelitian Fatmalasari et al (2016) bahwa petani sertifikasi telah merasakan manfaat ekonomi khususnya keadilan dalam proses transaksi. Hal ini ditunjukkan dengan rata-rata pendapatan petani sertifikasi sebesar Rp 10 920 999/ha sedangkan petani nonsertifikasi hanya sebesar Rp 8 962 978/ha.

\section{Pemasaran Kopi di Provinsi Sumatera Utara}

Sumatera Utara merupakan salah satu sentra produksi kopi terbesar ketiga di Indonesia dengan tingkat produksi mencapai 67179 ton pada tahun 2018 (BPS 2019). Jenis kopi yang dihasilkan di provinsi ini yaitu arabika dan robusta. Namun, kopi dengan jenis arabika mendominasi di provinsi ini. Tiga sentra produksi kopi di Provinsi Sumatera Utara diantaranya Kab. Tapanuli Utara, Kab. Simalungun, dan Kab. Dairi. Persentase kontribusi produksi ketiga kabupaten tersebut terhadap total produksi di provinsi ini secara berturut-turut sebesar 25.67 persen, 19.26 persen dan 16.04 persen.

Rantai pemasaran kopi arabika lebih panjang dan bervariasi dibandingkan dengan kopi robusta (Lingga dan Rijanta 2014). Pasar kopi robusta umumnya untuk memenuhi konsumen lokal sedangkan pasar kopi arabika umumnya untuk diekspor. Petani kopi umumnya menjual dalam bentuk cherry (buah kopi) atau kopi gabah. Petani menjual dalam bentuk cherry umumnya langsung dijual maksimal delapan jam setelah hasil panen. Umumnya petani yang menjual dalam bentuk cherry mendapatkan harga yang lebih rendah bila dibandingkan dalam bentuk gabah. Kopi dalam bentuk gabah telah melalui proses pengupasan kulit, sortasi dan setengah pengeringan. Petani dapat menjual kopi dalam bentuk cherry (buah kopi) atau kopi gabah ke pedagang pengumpul kecamatan atau kabupaten. Selanjutnya kopi dalam bentuk gabah dijual kembali pedagang besar sedangkan kopi yang dijual dalam bentuk cherry dijual ke pabrik untuk dilakukan proses lebih lanjut. Di tingkat pabrik dan pedagang besar inilah berbagai proses dilakukan hingga menjadi green bean. Berbeda halnya dengan kopi robusta yang diolah di tingkat industri kecil dan rumah tangga untuk dijual ke konsumen akhir.

Berdasarkan penelitian Triana et al (2013) terdapat petani yang menjual kopi setengah kering ke pedagang pengumpul kecamatan yang dilakukan setiap hari. Selanjutnya pedagang pengumpul kabupaten akan menerima kopi dari pedagang pengumpul kecamatan pada setiap akhir pekan. Selanjutnya biji kopi setengah kering tersebut dijual ke eksportir. Proses pengupasan kulit tanduk, pembersihan, hingga pengeringan biji dilakukan di tingkat eksportir hingga memenuhi kriteria ekspor. Kopi yang telah melalui proses tersebut akan diekspor melalui Kota Medan dalam bentuk biji kopi kering atau umumnya disebut kopi beras (greenbean). Kopi yang berasal dari Kab.Dairi tidak hanya dikonsumsi oleh konsumen lokal namun juga konsumen luar negeri seperti Amerika, Selandia Baru, dan Australia khususnya untuk memenuhi Starbuck.

\section{Pemasaran Kopi di Provinsi Aceh}

Tiga sentra produksi kopi di Provinsi Aceh tersebar dibeberapa kabupaten diantaranya Kab. Aceh Tengah, Kab. Bener Meriah, Kab. Gayo. Persentase produksi ketiga sentra produksi terhadap total produksi di provinsi tersebut secara berurutan yaitu 52.49 persen, 44.09 persen, dan 2.17 persen. Kopi Arabika Gayo merupakan komoditas utama di Provinsi tersebut. Produksi kopi dari provinsi tersebut diekspor ke pasar dunia 
sebanyak 86 persen (Putri et al 2013). Program sertifikasi produk dengan sistem pertanian berkelanjutan telah dilakukan petani kopi Arabika Gayo sejak tahun 1992 diantaranya Organic Certified, Fairtrade dan Raintforest. Pemasaran kopi Gayo telah mencapai pasar internasional seperti seperti Amerika Serikat, Eropa (Jerman, Inggris, Belanda) dan Asia (Korea, Kamboja, China, Arab Saudi) (Praza 2017).

Menurut Usman (2016), bahwa secara umum petani kopi Gayo menjual ke pedagang pengumpul desa dan pedagang pengumpul kecamatan. Selanjutnya sebagian besar kopi yang berada di pedagang pengumpul dijual kembali ke pedagang besar yang berada di kabupaten lalu dijual kembali ke eksportir. Disisi lain sebagian kecil dijual ke pedagang pengecer dan industri pengolah. Lembaga pemasaran lainnya selain lembaga pemasaran yang telah disebutkan sebelumnya yang terlibat di Provinsi Aceh khususnya di Kab. Aceh Tengah dan Kab. Bener Meriah yaitu koperasi (Putri et al 2013). Namun, perubahan harga kopi ditingkat pedagang pengumpul, koperasi, dan eksportir tidak ditransmisikan dengan baik ke tingkat petani (Putri et al 2013). Hal ini berdampak pada informasi pasar yang diperoleh sehingga petani memiliki keterbatasan memilih saluran pemasaran. Selain itu, struktur pasar kopi di Kab. Aceh Tengah dan Kab. Bener Meriah yang cenderung oligopsoni serta terbatasnya akses permodalan petani. Oleh karena itu, perlunya pengoptimalan koperasi dalam menginformasikan harga pasar baik harga lokal maupun harga dunia kepada petani (Juliavani et al 2017). Hal ini dikarenakan harga jual kopi merupakan faktor yang paling dominan mempengaruhi framer share (Usman (2016).

\section{Pemasaran Kopi di Provinsi Jawa Timur}

Jawa Timur merupakan salah satu sentra produksi kopi di Indonesia dengan tingkat produksi mencapai 63 760 ton pada tahun 2018. Kab. Malang menjadi sentra produksi terbesar dengan kontribusi produksi mencapai 31.89 persen dari total produksi di provinsi tersebut. Sentra produksi kopi lainnya yaitu Kab. Banyuwangi dengan persentase produksi mencapai 14.89 persen dari total produksi di Provinsi Jawa Timur. Selain itu, Kab. Jember menjadi sentra produksi kopi ketiga di Provinsi Jawa Timur dengan tingkat produksi mencapai 9.93 persen dari total produksi di provinsi tersebut. Jawa Timur memproduksi dua jenis kopi yaitu kopi arabika dan robusta. Namun, persentase produksi kopi robusta lebih tinggi dari kopi arabika yang mencapai 83.36 persen (Dirjenbun 2017).

Petani kopi di Kec.Silo Kab.Jember sebagian besar menghasilkan kopi dengan kualitas asalan dimana kadar air masih relatif tinggi dan menggunakan metode atau sarana yang masih sederhana (Novita et al 2012). Hal ini berdampak pada rendahnya harga yang diterima petani karena kopi yang dihasilkan merupakan kopi asalan (Rosiana 2019). Di wilayah tersebut, petani dapat menjual kopi ke tengkulak (pedagang pengumpul) atau mitra. Bahkan di Kec.Balik Bukit Kab.Jember seluruh petani menjual kopi ke pedagang pengumpul yang ada di Kec.Silo (Rahmadianto et al 2019). Penjualan kopi melalui mitra dilakukan dengan sistem kontrak dimana terdapat persyaratan-persyaratan seperti kualitas yang harus dipenuhi oleh petani. Namun, adanya kemudahan penyediaan "cash economy" oleh tengkulak maka mendorong petani lebih memilih menjual ke tengkulak daripada ke mitra. Di sisi lain, terdapat manfaat positif bila petani menjual melalui mitra dimana petani dapat mendapatkan harga lebih tinggi jika persyaratan kualitas dapat 
dipenuhi petani. Terdapat pola pemasaran lain yang dilakukan oleh petani di Kec.Bangsalsari Kab.Jember dimana petani tidak hanya menjual ke pedagang pengumpul pada saat setelah panen tetapi juga petani melakukan sistem ijon dimana buah kopi yang belum matang sempurna sudah dibeli terlebih dahulu (Yulian et al 2019). Pada sistem ijon, harga kopi tidak sesuai dengan harga pasar sehingga sistem tersebut merugikan petani (Zainuddin et al 2015). Kopi yang ada di pedagang pengumpul tersebut kemudian dijual ke pedagang besar atau pengolah untuk kemudian dipasarkan ke eksportir.

\section{Perbandingan Saluran Pemasaran Kopi di Setiap Provinsi}

Berdasarkan hasil analisis terdapat perbedaan saluran pemasaran di lima sentra produksi utama kopi Indonesia. Hal ini disebabkan perbedaan lembaga pemasaran yang terlibat, perlakuan khusus kopi, dan faktor jarak serta akses ke lembaga pemasaran. Adapun perbedaan saluran pemasaran kopi di lima sentra produksi kopi di Indonesia dapat dilihat pada Tabel 3.

Tabel 3. Saluran pemasaran kopi di lima sentra produksi utama kopi di Indonesia

\begin{tabular}{ll}
\hline \multicolumn{1}{c}{ Provinsi } & \multicolumn{1}{c}{ Saluran Pemasaran Kopi } \\
\hline Sumatera & 1. Petani $\rightarrow$ Pedagang Pengumpul $\rightarrow$ Pedagang Besar $\rightarrow$ Eksportir \\
Selatan & 2. Petani $\rightarrow$ Pedagang Pengumpul $\rightarrow$ Pengolah $\rightarrow$ Konsumen \\
\hline Lampung*) & 1. Petani Sertifikasi $\rightarrow$ Gapoktan $\rightarrow$ Buying Centre $\rightarrow$ \\
& Pengolah/Eksportir \\
& 2. Petani Non Sertifikasi $\rightarrow$ Pedagang Pengumpul $\rightarrow$ Pedagang Besar $\rightarrow$ \\
& Eksportir \\
& 3. Petani Non Sertifikasi $\rightarrow$ Pengolah $\rightarrow$ Konsumen \\
\hline Sumatera & 1. Petani $\rightarrow$ Pedagang Pengumpul Kecamatan/Kabupaten \\
Utara & $\rightarrow$ Pabrik/Pedagang Besar $\rightarrow$ Eksportir \\
& 2. Petani $\rightarrow$ Pedagang Pengumpul Kecamatan/Kabupaten $\rightarrow$ Industri \\
& Kopi Bubuk $\rightarrow$ Konsumen \\
& 3. Petani $\rightarrow$ Pedagang Pengumpul Kecamatan $\rightarrow$ Pedagang Pengumpul \\
& Kabupaten $\rightarrow$ Eksportir \\
& 4. Petani $\rightarrow$ Pedagang Pengumpul Kabupaten $\rightarrow$ Eksportir \\
5. Petani $\rightarrow$ Eksportir \\
\hline Aceh & 1. Petani $\rightarrow$ Pedagang Pengumpul Desa $\rightarrow$ Pedagang Pengumpul \\
& Kecamatan $\rightarrow$ Pedagang Besar Antar Kabupaten $\rightarrow$ Eksportir \\
& 2. Petani $\rightarrow$ Pedagang Pengumpul Desa $\rightarrow$ Pedagang Pengumpul \\
& Kecamatan $\rightarrow$ Pedagang Pengecer $\rightarrow$ Konsumen Akhir \\
& 3. Petani $\rightarrow$ Pedagang Pengumpul Desa $\rightarrow$ Pedagang Pengumpul \\
& Kecamatan $\rightarrow$ Industri Pengolah/Home Industri \\
4. Petani $\rightarrow$ Koperasi $\rightarrow$ Pengolah \\
\hline Jawa & 1. Petani $\rightarrow$ Pedagang Pengumpul $\rightarrow$ Pedagang Besar/Pengolah $\rightarrow$ \\
Timur**) & Eksportir \\
& 2. Petani $\rightarrow$ Mitra $\rightarrow$ Eksportir
\end{tabular}

Sumber : Nurlia dan Waluyo (2017), Pratiwi et al (2019), Triana et al (2013), Lingga dan Rijanta (2014), Usman (2016), Yulian et al (2019), Data Primer (diolah),

Ket :

*) Data primer

**) Data primer dan sekunder 


\section{Implikasi Kebijakan Pemasaran Kopi di Wilayah Sentra Produksi Utama}

Karakteristik kopi yang unik dan memiliki ciri khas dari setiap wilayah sentra produksi utama di Indonesia dapat dikembangkan mulai dari sisi hulu hingga hilir dalam mendorong peningkatan pasar kopi baik pasar dalam negeri maupun luar negeri. Dalam merespon tuntutan sertifikasi global pada proses pemasaran untuk menjamin kualitas kopi maka diperlukan keterangan asal-usul kopi dari setiap wilayah sentra produksi. Adanya dokumen Indikasi Geografis (IG) dalam setiap aktivitas pemasaran tersebut dapat mendorong peningkatan pasar kopi Indonesia.

Petani sebagai produsen utama didorong untuk meningkatkan kualitas melalui sistem pendampingan sertifikasi kopi. Selain itu, peningkatan kualitas kopi dalam aktivitas pemasaran dapat didukung melalui penguatan kelembagaan (kemitraan). Kemitraan tersebut dapat melalui Unit Pengelola Hasil (UPH), koperasi, atau contract farming dengan perusahaan. Hal ini dapat mengatasi permasalahan utama yang dihadapi oleh petani dalam aktivitas pemasaran yaitu keterbatasan informasi dan penentuan harga. Peningkatan peran petani dalam kemitraan dapat mendorong keberlanjutan produksi dan ekonomi petani kopi Indonesia. Upaya lain yang dapat dilakukan oleh petani dalam mengatasi rendahnya harga yang diterima melalui penjualan kopi bentuk biji kopi kering atau kopi beras atau mengolahnya dalam bentuk bubuk. Hal ini dikarenakan kopi dalam bentuk tersebut memiliki nilai tambah lebih tinggi dibandingkan dengan menjual dalam bentuk biji setengah kering. Meskipun petani mengeluarkan biaya lebih besar dalam proses pengolahan namun harga jual yang diperoleh petani akan lebih tinggi. Selain itu, dilakukannya proses tersebut dapat meningkatkan masa simpan sehingga memungkinkan petani untuk dapat menjual biji kopi atau kopi bubuk ketika berada pada harga tinggi. Hal ini mendorong petani dapat memiliki alternatif pola pemasaran yang dapat memberikan manfaat ekonomi lebih tinggi.

\section{SIMPULAN}

Petani kopi di lima sentra produksi utama Indonesia menjual kopi dalam bentuk kopi asalan yang secara umum menjual ke pedagang pengumpul. Adanya kemudahan cash economy dan tidak ada perlakuan khusus untuk kopi yang dijual menjadi alasan utama petani menjual kopi ke pedagang pengumpul. Meskipun disisi lain harga yang diperoleh belum sesuai dengan keinginan petani. Oleh karena itu, pentingnya pola pemasaran kopi yang dapat meningkatkan manfaat ekonomi bagi petani. Hal tersebut dapat dilakukan dengan cara memperkuat posisi tawar para produsen kopi melalui penguatan kelembagaan (kemitraan) pada sistem pemasaran sehingga keterbatasan dalam informasi dan penentuan harga dapat diatasi. Selain itu, dalam meningkatkan manfaat ekonomi petani dapat dilakukan dengan menjual biji kopi kering atau kopi beras secara kolektif dalam suatu hamparan wilayah. Hal ini memungkinkan petani mendapatkan harga lebih tinggi dibandingkan ketika menjual kopi setengah kering. Hal ini dapat meningkatkan masa simpan sehingga petani dapat melakukan sistem tunda jual ketika harga sesuai. Selain itu, petani dapat melakukan pengolahan lebih lanjut menjadi kopi bubuk sehingga dapat meningkatkan nilai tambahn. Hal lainnya yang dapat dilakukan yaitu perlunya pendampingan petani yang diarahkan pada proses sertifikasi yang berkelanjutan baik dari sisi produksi maupun ekonomi. 


\section{DAFTAR PUSTAKA}

[BPS]. Badan Pusat Statistik. 2019. Statistik Kopi Indonesia 2018. BPS. Jakarta (ID).

[Dirjenbun]. Direktorat Jenderal Perkebunan. 2017. Statistik Perkebunan Indonesia 2016-2018. Sekretariat Direktorat Jenderal Perkebunan, Direktorat Jenderal Perkebunan, Kementerian Pertanian. Jakarta.

Cristovao. 2015. Analisis efisiensi pemasaran dan pilihan saluran pemasaran kopi organik di Kabupaten Ermera - Timor Leste. Tesis. Institut Pertanian Bogor.

Fatmalasari, M., Prasmatiwi FE., Rosanti N. 2016. Analisis manfaat sertifikasi Indonesian Organic Farm Certification (INOFICE) terhadap keberlanjutan usahatani kopi organik di Kecamatan Air Hitam Kabupaten Lampung Barat. Jurnal Ilmu-Ilmu Agribisnis. 4:30-39.

Juliavani, N., Sahara., Winandi, R. 2017. Transmisi harga kopi Arabika Gayo di Provinsi Aceh. Jurnal Agribisnis Indoensia. 5:39-56.

Lingga, SS., Rijanta R. 2014. Rantai distribusi kopi dalam peningkatan kesejahteraan petani kopi di Kabupaten Dairi. Jurnal Bumi Indonesia. 3:1-9.

Markoni. 2012. Hambatan eksportir kopi Sumsel melakukan penetrasi pasar luar negeri. Jurnal Orasi Bisnis. 7:39-46.

Noer, I., Fitriani., Agus. 2012. Integrasi pasar kopi di Provinsi Lampung. Jurnal Ilmiah Esai. 6;1-8.

Novita, E., Suryaningrat, IB., Andriyani, I., Widyotomo, S. 2012. Analisis keberlanjutan kawasan usaha perkebunan kopi (KUPK) rakyat di Desa Sidomulyo Kabupaten Jember. Jurnal Agritech. 32:1-15.

Pratiwi, AM., Kaskoyo H., Herwanti S., Qurniati R. 2019. Saluran pemasaran kopi robusta (Coffea robusta) di agroforestri Pekon Air Kubang, Kecamatan Air Naningan, Kabupaten
Tanggamus. Jurnal Belantara. 2:7683.

Praza, R. 2017. Identifikasi saluran pemasaran kopi Arabika Gayo pada CV. Gayo Mandiri Coffee Kabupaten Bener Meriah. Jurnal Agribisnis Universitas Malikussaleh. 2:58-64.

Purwatiningsih, $\mathrm{R}$ dan Ismanto, A. Struktur pasar dan analisis keuntungan kopi arabika rakyat di Kecamatan Sumber Wringin Bondowoso. Jurnal Sosial Ekonomi Pertanian. 11: 17-21.

Putri, MA., Fariyanti, A., Kusnadi N. 2013. Struktur dan integrasi pasar kopi Arabika Gayo di Kabupaten Aceh Tengah dan Bener Meriah. Buletin Ristri. 4:47-54.

Rahmadianto, AP., Ikhsan FA., Apriyanto B. 2019. Peran pengembangan perkebunan kopi terhadap kondisi ekonomi masyarakat Desa Pace Kecamatan Silo Kabupaten Jember. Jurnal Geografi Gea. 19:84-87.

Ridhawardani, A., Pardian, P., Mukti, GW. 2017. Analisis efisiensi pemasaran bunga mawar potong di Desa Kertawangi, Kecamatan Cisarua, Kabupaten Bandung Barat. Jurnal Agrosains dan Teknologi. 2: 13-21.

Rosiana, N. 2019. Dayasaing dan ekspor kopi Indonesia melalui pendekatan sistem dinamis. Disertasi. Institut Pertanian Bogor.

Rosiana, N., Nurmalina, R., Winandi, R., Rifin A. 2017a. Efficiency Analysis of Indonesian Coffee Supply Chain Network Using A New DEA Model Approach: Literature Review. Asian Social Science. 13:158-166.

Rosiana, N., Nurmalina, R., Winandi, R., Rifin A. 2017b. The Level of Comparative Advantage of World Main Coffee Producers. Trade Analysis and Development Agency Ministry of Trade, Republic of Indonesia, 11:227-246.

Rosiana, N., Nurmalina, R., Winandi, R., Rifin A. 2018. Dynamics of Indonesian Robusta Coffee 
Competition Among Major Competitor Countries. Journal of Industrial and Beverage Crops,Indonesian Center for Estate Crops Research and Development. 5:1-9.

Triana, R. 2013. Analisis sistem pemasaran kopi pembinaan di Kabupaten Dairi Provinsi Sumatera Utara. Agrica (Jurnal Agribisnis Sumatera Utara). 6:34-43.

Usman, M. 2016. Analisis pengaruh beberapa faktor terhadap "farmer share"pada sistem pemasaran kopi arabika di Kabupaten Bener Meriah Provinsi Aceh. Jurnal Bisnis Tani. 2:123-131.

Waluyo, EA., Nurlia, A. 2017. Potensi pengembangan kopi Liberika (Coffea liberica) pola agroforestri dan prospek pemasarannya untuk mendukung restorasi lahan gambut di Sumatera Selatan (Belajar dari Kab. Tanjung Jabung Barat, Provinsi Jambi). Prosiding Seminar Nasional Lahan Suboptimal 2017. 255-264.

Yulian, NF., Kuswardhani, N., Amilia W. 2019. Identifikasi dan analisis struktur rantai pasok kopi rakyat robusta Kecamatan Bangsalsari, Jember. Jurnal Agroteknologi. 13: 10-15.

Zainuddin, S., Martini, E., Perdana, A., Roshetko, M. 2015. Kualitas, kuantitas dan pemasaran kopi arabika dari kebun agroforestry di Kabupaten Bantaeng, Sulawesi Selatan. Prosiding Seminar Nasional Agrofestry. 562-566. 